\title{
Uji Aktivitas Antipiretik Kombinasi Ekstrak Etanol Herba Meniran (Phyllanthus niruri L.) dan Daun Sambung Nyawa (Gynura procumbens L.) Pada Mencit yang Diinduksi Ragi
}

\author{
Adistyara Nur Faizah ${ }^{1 *}$, Wisnu Kundarto ${ }^{2}$ dan Heru Sasongko ${ }^{2}$ \\ ${ }^{1}$ Program Studi Farmasi, Fakultas Matematika dan Ilmu Pengetahuan Alam, Universitas Sebelas Maret, Jl. Ir. \\ Sutami 36A, Surakarta, Indonesia, 57126. \\ ${ }^{2}$ Program Studi D3 Farmasi, Sekolah Vokasi, Universitas Sebelas Maret, J1. Ir. Sutami 36A, Surakarta, Indonesia, \\ 57126. \\ *email korespondensi: adistyara@ @student.uns.ac.id \\ Received 20 March 2021, Accepted 02 November 2021, Published 15 November 2021
}

\begin{abstract}
Abstrak: Demam merupakan kondisi terjadinya kenaikan suhu tubuh di atas suhu normal. Demam terjadi sebagai bagian dari mekanisme pertahanan tubuh melawan infeksi. Penelitian terdahulu, meniran dan sambung nyawa mengandung flavonoid dan secara ilmiah ekstrak tunggal kedua tanaman tersebut memiliki aktivitas antipiretik. Tujuan penelitian ini adalah untuk mengetahui aktivitas antipiretik kombinasi ekstrak etanol herba meniran dan daun sambung nyawa pada mencit yang diinduksi ragi dan untuk membandingkan dengan ekstrak tunggalnya. Penelitian ini merupakan penelitian eksperimental dengan menggunakan Rancangan Acak Lengkap. Pengujian antipiretik pada penelitian ini mencit diinduksi ragi dengan dosis $20 \mathrm{~mL} / \mathrm{kgBB}$ secara subkutan dan diukur suhu badan melalui rektal. Kelompok uji dibagi menjadi 8 kelompok yaitu kelompok kontrol positif (Parasetamol 1,3 mg/20 gram BB mencit), kontrol normal, kontrol negatif (CMC-Na), ekstrak daun sambung nyawa (EDS) mengandung $10 \mathrm{mg} / \mathrm{kgBB}$ mencit kuersetin (100\%), ekstrak herba meniran (EHM) mengandung $10 \mathrm{mg} / \mathrm{kgBB}$ mencit kuersetin (100\%); EDS 75\% : EHM 25\%; EDS 50\% : EHM 50\%; dan EDS 25\% : EHM 75\% yang diinjeksikan secara intraperitoneal pada mencit. Pengukuran suhu dilakukan dengan interval waktu 30 menit selama 5 jam. Hasil penelitian menunjukkan bahwa nilai AUC semua kelompok perlakuan memiliki perbedaan yang signifikan $(p \leq 0,05)$ dengan kontrol negatif, yang artinya ekstrak tunggal maupun ekstrak kombinasi herba meniran dan daun sambung nyawa memiliki aktivitas antipiretik. Ekstrak kombinasi herba meniran dan daun sambung nyawa tidak lebih baik dalam menurunkan demam dibandingkan dengan ekstrak tunggalnya. Dosis tunggal ekstrak daun sambung nyawa memiliki aktivitas antipiretik yang paling baik karena memiliki nilai AUC yang paling kecil $(10.549,50)$.
\end{abstract}

Kata kunci: antipiretik; Gynura procumbens L.; Phyllanthus niruri L.

Abstract. Activity Test of Antipyretic from Combination of Ethanol Extracts Meniran Herbs (Phyllanthus niruri L.) and Sambung Nyawa Leaves (Gynura procumbens L.) in Yeast-Induced Mice. Fever is a condition of an increase in body temperature above normal temperature. Fever can occur as part of the body's defense mechanism against infection. The previous research, meniran herbs and sambung nyawa leaves contain flavonoids and scientifically the single extract of meniran herbs and sambung nyawa leaves has an antipyretic effect, so meniran herbs and sambung nyawa leaves are thought to have an antipyretic effect. The aim of this study was to find out the antipyretic activity from combination of ethanol extract of meniran herbs and sambung nyawa leaves in yeast-induced mice and to compare with the single dose extract. This study was an experimental study using a completely randomized design. The antipyretic test in this study was induced by yeast with a subcutaneous dose of 20 $\mathrm{mL} / \mathrm{kg}$ and body temperature was measured rectally. The antipyretic test in this study was 
divided into 8 groups : positive control group (Paracetamol 1,3 mg/20 grams of body weight in mice), normal control, negative control (CMC-Na), sambung nyawa leaf extract containing 10 $\mathrm{mg} / \mathrm{kgBB}$ mice quercetin (100\%), meniran herbs extract containing $10 \mathrm{mg} / \mathrm{kgBB}$ mice quercetin (100\%) EDS 75\%: EHM 25\%; EDS 50\%: EHM 50\%; and EDS 25\%: EHM 75\% that was injected intraperitoneally in mice. Temperature measurements were carried out at intervals of 30 minutes for 5 hours. The results showed that the AUC values of all treatment groups had a significant difference $(p \leq 0,05)$ with the negative control, which meant that either the single extract or the combined extract of meniran herbs and life-long leaves had antipyretic activity. The combined extract of meniran herbs and continued life leaves was not better in reducing fever compared to the single extract. A single dose of leaf extract has shown the best antipyretic activity because it has the smallest AUC value $(10.549,50)$.

Keywords: antipyretic; Gynura procumbens L.; Phyllanthus niruri L.

\section{Pendahuluan}

Demam merupakan peningkatan suhu tubuh di atas normal yang terjadi karena adanya gangguan pada pusat pengatur panas di hipotalamus, suhu tubuh normal berkisar antara $36^{\circ}-$ $37^{\circ} \mathrm{C}$. Peningkatan suhu tubuh pada keadaan patologi diawali dengan pelepasan suatu zat pirogen endogen atau sitoksin seperti inteleukin-1 yang memacu pelepasan prostaglandin yang berlebihan di daerah preoptik hipotalamus (Guyton \& Hall, 1997). Demam dapat diturunkan dengan menggunakan obat penurun demam atau antipiretik. Antipiretik adalah obat yang menurunkan suhu tubuh yang tinggi (Budiman, 2018). Mekanisme antipiretik erat kaitannya dengan mekanisme analgetik, karena bekerja pada enzim yang sama yaitu menghambat enzim siklooksigenase (COX) yang berperan dalam pembentukan prostaglandin sebagai mediator nyeri, penghambatan enzim COX ini akan menghambat timbulnya rasa nyeri (Irwandi et al., 2018).

Masyarakat lebih memilih untuk back to nature saat ini karena dilihat dari penggunaan obat-obatan kimia yang banyak menimbulkan efek samping. Beberapa tanaman herbal yang memiliki aktivitas sebagai antipiretik adalah daun meniran (Phyllanthus niruri L.) dan daun sambung nyawa (Gynura procumbens L.). Meniran (P. niruri) merupakan salah satu tanaman berkhasiat obat yang secara empiris digunakan masyarakat di Indonesia sebagai pengobatan demam. Penelitian yang dilakukan Bagalkotkar et al. (2006) menunjukkan bahwa meniran mengandung senyawa flavonoid yaitu kuersetin, kuersitrin dan rutin. Penelitian yang dilakukan Sasongko et al. (2016) didapatkan ekstrak daun carica yang memiliki kandungan flavonoid, memiliki aktivitas penghambatan enzim siklooksigenase dengan cara mengurangi produksi prostaglandin oleh asam arakidonat. Penelitian yang dilakukan Jansen et al. (2015) dalam uji efek antipiretik ekstrak meniran pada tikus wistar jantan yang diinduksi vaksin DPT-HB, diketahui bahwa ekstrak tunggal meniran secara ilmiah memiliki efek sebagai antipiretik. Senyawa lain yang terkandung dalam meniran yang memiliki aktivitas analgesik dan antipiretik adalah tanin. Penelitian yang dilakukan Kaur et al. (2017) menunjukkan bahwa korilargin dan 
geranin adalah salah satu golongan tanin yang terdapat dalam meniran dan dibuktikan memiliki efek analgesik. Korilargin dan geranin merupakan jenis tanin terhidrolisis (Cheng et al., 2017). Tanin khususnya korilargin dan geranin bekerja dengan menghambat pelepasan sitokin yang merupakan mediator demam (Moreira et al., 2013).

Sambung nyawa (G.procumbens) adalah tanaman yang secara turun-temurun telah banyak digunakan untuk pengobatan (Rivai et al., 2011). Secara empiris, daun sambung nyawa dipercaya dapat digunakan untuk mengobati penyakit demam (Winarto \& Karyasari, 2003). Penelitian Kaewseejan et al., (2012), ekstrak etanol dari sambung nyawa mengandung senyawa flavonoid, terutama mirisetin dan kaemferol. Menurut penelitian Rahmi (2019) ekstrak daun sambung nyawa (Gynura procumbens L.) yang diuji aktifitas antipiretik pada tikus putih jantan dengan induksi demam menggunakan larutan vaksin DPT-HB dan dilakukan skrining fitokimia pada ekstrak etanol daun sambung nyawa, didapatkan hasil dari penelitian tersebut bahwa adanya senyawa flavonoid pada ekstrak daun sambung nyawa yang memiliki efek sebagai antipiretik pada tikus putih jantan yang diinduksi demam menggunakan larutan vaksin DTPHB.

Penelitian sebelumnya menunjukkan bahwa ekstrak kombinasi memiliki efek yang lebih baik dibandingkan dengan ekstrak tunggalnya. Penelitian yang dilakukan Ibrahim et al. (2014) didapatkan bahwa ekstrak kombinasi lebih cepat dalam menurunkan suhu demam. Penelitian sebelumnya yang telah dilakukan oleh Jansen et al. (2015). Efek antipiretik dalam ekstrak tunggal meniran dan sambung nyawa sehingga jika kedua tanaman dikombinasikan, diduga akan memberikan efek yang sinergis (Rahmi, 2019). Belum adanya penelitian terkait uji antipiretik dari kombinasi ekstrak daun meniran (Phyllanthus niruri L.) dan daun sambung nyawa (Gynura procumbens L.), juga melatarbelakangi peneliti untuk melakukan penelitian ini. Tujuan dari penelitian ini adalah untuk mengetahui adanya aktivitas antipiretik pada herba meniran (Phyllanthus niruri L.) dan daun sambung nyawa (Gynura procumbens L.) serta untuk membandingkan antara ekstrak tunggal dan kombinasi yang memberikan efek antipiretik yang lebih baik.

\section{Bahan dan Metode}

Penelitian ini adalah metode eksperimental laboratories dengan menggunakan rancangan penelitian percobaan RAL (Rancangan Acak Lengkap). Penelitian dilakukan secara in vivo dengan menggunakan hewan uji mencit putih jantan sebanyak 40 ekor yang dibagi menjadi 8 kelompok uji. 


\subsection{Alat dan bahan}

Bahan uji yang digunakan adalah herba meniran (Phyllanthus niruri L.) yang didapatkan dari Karanganyar, Jawa Tengah dan daun sambung nyawa (Gynura procumbens L.) yang didapatkan dari Boyolali, Jawa Tengah yang di ekstrak dengan menggunakan pelarut etanol 70\%. Bahan yang digunakan untuk uji kuantitatif adalah etanol $96 \%$ p.a (Emsure), $\mathrm{AlCl}_{3}$, kalium asetat, sitroborat, alumunium foil (Laboratorium Farmasi), kertas saring (Laboratorium Farmasi) dan standar kuersetin. Bahan yang digunakan untuk uji kualitatif flavonoid adalah serbuk magnesium dan $\mathrm{HCl}$ pekat (Laboratorium Farmasi), sedangkan untuk uji kualitatif tanin adalah larutan besi (1ll) klorida (Laboratorium Farmasi). Bahan yang digunakan untuk uji antipiretik adalah aquadest (Laboratorium Farmasi), CMC-Na (Laboratorium Farmasi), tablet parasetamol generik $500 \mathrm{mg}$ produksi PT. Mersifarma TM, ragi tape merk NKL (Pasar Gedhe Surakarta) dan hewan uji mencit putih (Mus muculus) jantan galur Swiss Webster dan pakan mencit yang diperoleh dari peternakan "Boss Tikus” Ngargoyoso, Karanganyar, Jawa Tengah.

\subsection{Ekstraksi herba meniran dan daun sambung nyawa}

Ekstraksi herba meniran dan daun sambung nyawa mengacu pada Farmakope Herbal Indonesia edisi 2 (2017) menggunakan metode ekstraksi dingin yaitu dengan maserasi. Pelarut yang digunakan dalam proses ekstraksi adalah etanol teknis $70 \%$ karena dinyatakan bahwa golongan senyawa flavonoid dapat diekstrak dengan baik menggunakan pelarut etanol $70 \%$ (Harborne, 2006). Ekstraksi dilakukan dengan menggunakan etanol yang merupakan pelarut universal (Snyder et al., 2009) dengan melarutkan 250 gram serbuk simplisia kering dalam 1 liter pelarut dan dilakukan perendaman selama 5 hari tanpa dilakukan remaserasi. Ekstraksi herba meniran, dari 250 gram serbuk simplisia kering didapatkan ekstrak kental berwarna hijau pekat dan berbau khas dengan berat sebesar 12,624 gram ekstrak kental, sedangkan pada simplisia daun sambung nyawa dari 400 gram serbuk kering didapatkan ekstrak kental berwarna hijau pekat, berbau khas dengan berat sebesar 111,810 gram ekstrak kental. Kondisi lingkungan tempat tumbuhan tumbuh seperti curah hujan, lama paparan sinar matahari, $\mathrm{pH}$ air laut, kadar garam, dan suhu akan mempengaruhi kandungan fenol dan flavonoid (Andayani \& Nugrahani, 2018).

\subsection{Uji kualitatif dan kuantitatif}

Analisis kualitatif digunakan untuk menguji keberadaan senyawa flavonoid dan tanin pada ekstrak. Uji flavonoid yang digunakan adalah dengan metode perubahan warna Uji Wilstatter, yaitu dengan mereaksikan sampel ekstrak dengan magnesium dan $\mathrm{HCl}$ (Lumowa \& Bardin, 2018). Uji tanin dilakukan dengan mereaksikan sampel ekstrak dengan larutan besi (III) 
klorida (Departemen Kesehatan Republik Indonesia, 1995). Uji kuantitatif flavonoid dilakukan dengan menggunakan metode kolorimetri dengan standar baku kuersetin (Chang et al., 2002).

\subsection{Uji antipiretik}

Pengujian antipiretik dilakukan dengan menyiapkan hewan uji mencit putih (Mus musculus) jantan galur swiss webster usia 2-3 bulan dengan berat badan 12-35 gram sebanyak 40 ekor. Pembagian jumlah hewan uji pada setiap kelompok didasarkan pada rumus federer dan didapatkan nilai $\mathrm{n}$ sebesar $\geq 3,14$ dan pada penelitian ini jumlah hewan uji pada setiap kelompok adalah 5 ekor. Mencit putih diaklimatisasi selama 1 minggu. Mencit dipuasakan terlebih dahulu selama \pm 12 jam sebelum pengujian. Agen penginduksi demam yang digunakan dalam penelitian ini adalah ragi (Saccharomyces cereviceae) merk NKL yang diperoleh dari Surakarta, Jawa Tengah. Ragi sebagai agen penginduksi demam diberikan secara subkutan yaitu disuntikkan ke dalam jaringan dibawah kulit. Pengukuran suhu rektal dilakukan pada saat sebelum diinduksi ragi dan 3 jam setelah mencit diinduksi ragi. Apabila mencit sudah mengalami demam, dilakukan induksi bahan uji dan dilakukan pengukuran suhu badan dengan interval 30 menit selama 5 jam setelah perlakuan. Induksi bahan uji dilakukan secara intra peritoneal yaitu dengan disuntikkan langsung ke dalam rongga perut. Perlakuan yang diberikan pada kelompok kontrol positif yaitu dengan diberikan parasetamol tablet $500 \mathrm{mg}$ secara intraperitoneal dengan penyesuaian konversi dosis ke mencit dan diperoleh dosis sebesar 1,3 mg/20 gram BB mencit. Dosis ekstrak yang diberikan dihitung dari dosis kuersetin sebagai antipiretik yaitu sebesar $10 \mathrm{mg} / \mathrm{kg}$ BB (Valério et al., 2009). Dosis masing-masing kelompok pada penelitian ini adalah : Ekstrak daun sambung nyawa (EDS) 100\%, Ekstrak herba meniran (EHM) 100\%, EDS 75\% : EHM 25\%, EDS 50\% : EHM 50\%, dan EDS 25\% : EHM 75\%.

\subsection{Analisis data}

Data yang diperoleh berupa suhu badan mencit yang kemudian dianalisis secara statistik dengan software IBM SPSS statistic 25. Kemudian dilakukan uji normalitas Shapiro-wilk dan uji Levene (homogenitas). Data yang memenuhi kriteria normalitas dan homogenitas kemudian dilakukan analisis parametrik one-way ANOVA dan post-hoc LSD.

\section{Hasil dan Pembahasan}

Penelitian ini dilakukan dengan mengajukan proposal kepada pihak program studi S1 Farmasi UNS dan telah mendapatkan surat Ethical Clearance oleh Komisi Etik Penelitian Kesehatan RSUD Dr. Moewardi Nomor : 1.190/X/HREC/2020 dan mendapatkan ijin penelitian dari Laboratorium Farmasi FMIPA UNS dan UPT Laboratorium Terpadu UNS. 


\subsection{Uji kualitatif dan kuantitatif pada ekstrak}

Ekstrak kental herba meniran dan daun sambung nyawa yang diperoleh sebanyak masingmasing 27,9525\% untuk ekstrak daun sambung nyawa dan 5,0496\% untuk ekstrak herba meniran. Hasil uji kualitatif tanin dan uji flavonoid dapat dilihat pada Tabel 1.

Tabel 1. Hasil uji kualitatif tanin dan flavonoid pada ekstrak herba meniran dan ekstrak daun sambung nyawa.

\begin{tabular}{cllc}
\hline Jenis Uji & \multicolumn{1}{c}{ Ekstrak } & \multicolumn{1}{c}{ Hasil } & Kesimpulan \\
\hline \multirow{2}{*}{ Tanin } & Daun sambung nyawa & $\begin{array}{l}\text { Terjadi perubahan warna dari hijau } \\
\text { kekuningan menjadi hijau kehitaman }\end{array}$ & + \\
\cline { 2 - 4 } Flavonoid & Herba meniran & $\begin{array}{l}\text { Terjadi perubahan warna dari hijau } \\
\text { kecoklatan menjadi biru kehitaman }\end{array}$ & + \\
\cline { 2 - 5 } & Derba meniran & $\begin{array}{l}\text { Terjadi perubahan warna dari hijau } \\
\text { kehitaman menjadi hijau kemerahan } \\
\text { menjadi coklat kemerahan }\end{array}$ & + \\
\hline
\end{tabular}

Uji kuantitatif atau uji penetapan kadar total flavonoid dilakukan dengan menggunakan standar kuersetin. Kuersetin dipilih sebagai larutan pembanding karena merupakan salah satu senyawa golongan flavonoid yang dapat bereaksi dengan $\mathrm{AlCl}_{3}$ membentuk kompleks (Chang et al., 2002). Panjang gelombang yang digunakan pada penelitian adalah $433 \mathrm{~nm}$. Konsentrasi kurva baku yang digunakan pada penelitian ini adalah 100 ppm, 87,5 ppm, 75 ppm, 50 ppm, $37,5 \mathrm{ppm}, 25 \mathrm{ppm}, 12,5 \mathrm{ppm}, 6,25 \mathrm{ppm}$. Konsentrasi ini dipilih karena absorbansinya memenuhi atau mendekati nilai absorbansi yang baik dan sampel dapat masuk pada rentang tersebut.

Penetapan kadar flavonoid dari ekstrak etanol herba meniran dan daun sambung nyawa dilakukan secara triplo dan dari hasil absorbansi didapatkan kurva baku yaitu $\mathrm{y}=0,0074 \mathrm{x}+$ 0,0304 dengan nilai $\mathrm{r}$ atau linieritas sebesar 0,997 . Nilai $\mathrm{r}$ yang mendekati satu menunjukkan bahwa terdapat korelasi yang baik antara kadar kuersetin dan absorbansi. Gambar kurva baku dari kuersetin dapat dilihat pada Gambar 1.

Ekstrak herba meniran dan daun sambung nyawa masing-masing dibuat dengan konsentrasi 2000 ppm dan di absorbsi pada panjang gelombang $433 \mathrm{~nm}$. Hasil dari absorbansi didapatkan kadar total flavonoid untuk ekstrak herba meniran adalah 659 mg QE / 100 gram ekstrak dan untuk ekstrak daun sambung nyawa didapatkan total flavonoid sebesar $2.510 \mathrm{mg}$ QE / 100 gram ekstrak. Menurut Valério et al. (2009) dalam penelitiannya tentang uji analgesik dengan kuersetin pada mencit dengan cara diinduksikan secara intraperitonial, didapatkan bahwa dosis kuersetin sebesar $10 \mathrm{mg}$ dapat memberikan efek analgesik yang baik dan berbeda signifikan dengan kontrol negatif. Dosis tunggal meniran yang didapatkan dari perhitungan 
sebesar 1.517,45 mg/kg BB dan dosis tunggal sambung nyawa yang didapatkan sebesar 398,4 $\mathrm{mg} / \mathrm{kg} \mathrm{BB}$.

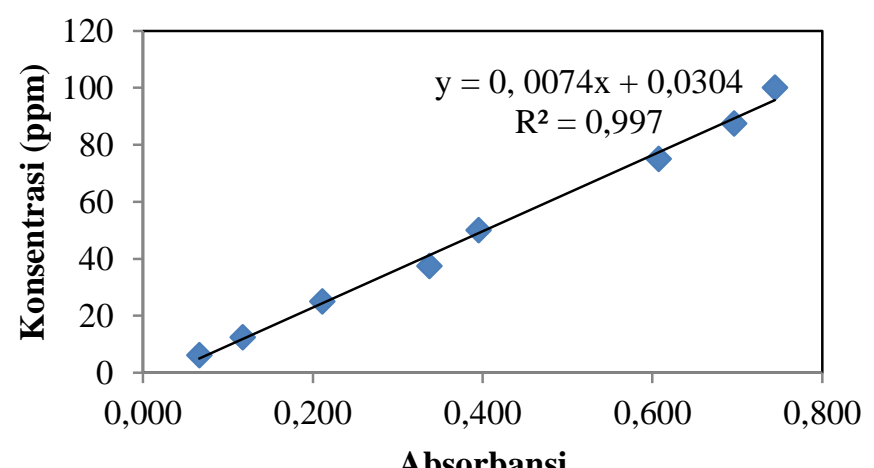

Gambar 1. Kurva baku standar kuersetin dengan seri konsentrasi 100 ppm, 87,5 ppm, 75 ppm, 50 ppm, 37,5 ppm, 25 ppm, 12,5 ppm, dan 6,25 ppm pada absorbansi $433 \mathrm{~nm}$.

\subsection{Uji antipiretik}

Hewan uji yang digunakan pada penelitian ini adalah mencit putih jantan galur Swiss Webster dengan berat 12-35 gram sejumlah 40 ekor yang terbagi dalam 8 kelompok uji dengan 5 ekor mencit pada tiap kelompoknya. Sebelum dilakukan pengujian, hewan diaklimatisasi dahulu selama 7 hari atau lebih dengan tetap diberikan makan dan minum. Tujuan dilakukannya aklimatisasi adalah untuk membiasakan mencit pada lingkungan yang baru sehingga dapat menghindari stres pada mencit yang dapat mengganggu pengujian (Edwin et al., 2017). Suspensi ragi yang digunakan sebagai penginduksi demam dibuat dengan konsentrasi $20 \%$, yaitu dengan melarutkan 20 gram ragi dalam $100 \mathrm{ml}$ larutan fisiologis $\mathrm{NaCl}$ 0,9\% (Sasongko et al., 2019). Menurut Tesema \& Makonnen (2015) mencit mengalami demam ketika suhu mencit naik minimal $0,5^{\circ} \mathrm{C}$ setelah penyuntikan ragi secara subkutan. Grafik perubahan suhu mencit dapat dilihat pada Gambar 2.

Data hasil pengukuran antipiretik, data yang diukur berupa kenaikan atau penurunan suhu mencit yang diukur melalui rektal (Gambar 2). Keterangan T0 menunjukkan suhu awal hewan uji sebelum diinduksi ragi, sedangkan $\mathrm{T}$ demam menunjukkan suhu hewan 3 jam setelah diinduksi ragi. Suhu tubuh mencit diukur selama 300 menit, pengukuran tersebut didasarkan pada aturan pakai parasetamol yaitu tiap 4-6 jam sekali dengan maksimal pemberian 4 gram dalam 24 jam (Sweetman, 2009). Dalam penelitian ini digunakan kontrol normal dengan tujuan untuk membandingkan suhu tubuh normal mencit. Kontrol negatif dalam penelitian ini menggunakan CMC-Na karena tidak memberikan pengaruh terhadap suhu tubuh mencit. Kontrol positif yang digunakan adalah parasetamol tablet dengan kekuatan tablet $500 \mathrm{mg}$ per tablet. Parasetamol termasuk obat golongan NSAID yang digunakan sebagai lini pertama saat terjadinya demam (Martino \& Chiarugi, 2015). Gambar 2, grafik kontrol positif menunjukkan 
penurunan suhu yang baik dibandingkan dengan kontrol negatif. Rata-rata suhu setelah induksi ragi pada tiap kelompok tidak berbeda jauh dengan suhu sebelum diinduksi ragi, hal ini dapat dipengaruhi oleh termoregulasi dalam diri hewan yang berbeda-beda, hal lain yang dapat mempengaruhi adalah faktor lingkungan dan dosis ragi yang rendah.

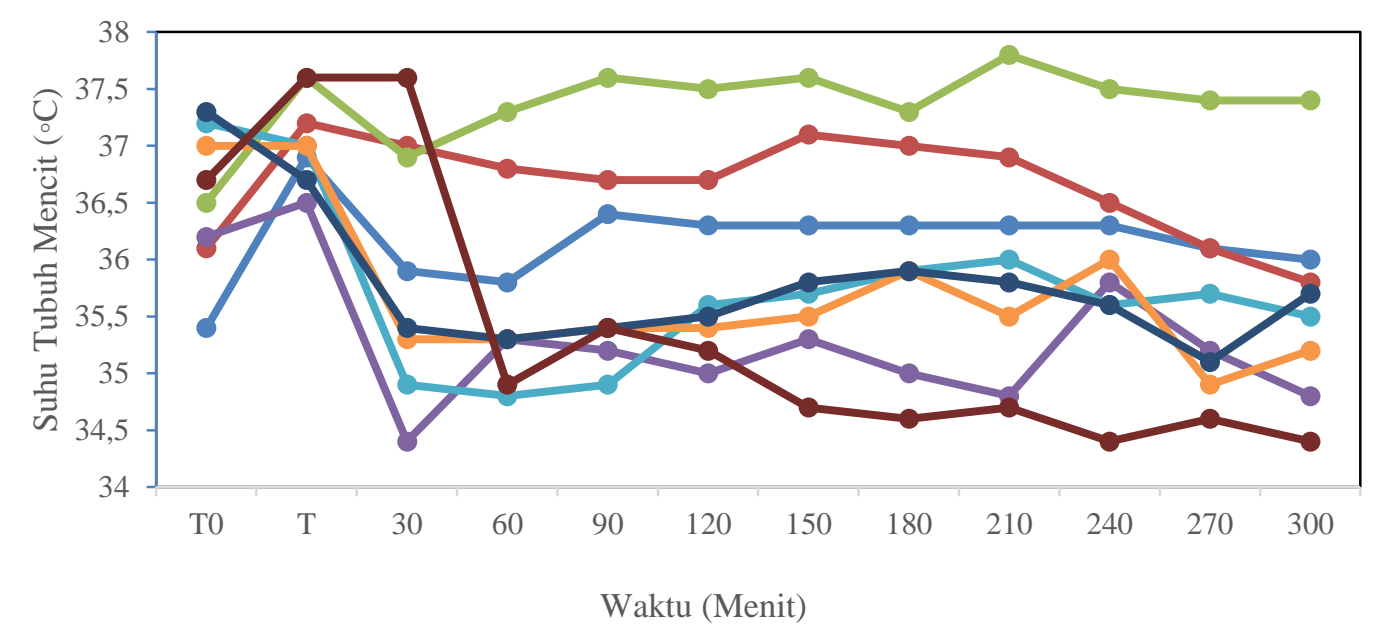

Gambar 2. Grafik suhu tubuh mencit yang diinduksi demam dengan ragi dan diinduksi dengan larutan uji. Kontrol Positif (-), Kontrol Normal (-), Kontrol Negatif (-), Sambung Nyawa 100\% (-), Meniran 100\% (-), Sambung Nyawa 75\%+Meniran $25 \%$ (-), Sambung Nyawa 50\%+Meniran 50\% (-), Sambung Nyawa $25 \%+$ Meniran $75 \%$ (-).

Suhu tubuh mencit yang didapat kemudian digunakan untuk menghitung Area Under Curve (AUC). Area Under Curve (AUC) atau area dibawah kurva digunakan untuk melihat gambaran efek penurunan suhu tubuh hewan uji. Semakin kecil nilai AUC, maka efek penurunan suhu semakin baik. Suhu tubuh hewan uji yang diamati selama 300 menit. Hasil perhitungan AUC suhu tubuh mencit dapat dilihat pada Tabel 2.

Tabel 2. Data AUC suhu tubuh mencit yang diinduksi larutan uji dan diukur selama 300 menit. Keterangan : Dosis $1=$ Sambung Nyawa $75 \%+$ Meniran 25\%, Dosis $2=$ Sambung Nyawa 50\% + Meniran 50\%, Dosis $3=$ Sambung Nyawa 25\% + Meniran 75\%.

\begin{tabular}{cc}
\hline Kelompok Perlakuan & AUC Suhu Tubuh $\left({ }^{\circ} \mathbf{C}\right) \pm$ SD \\
\hline Kontrol Positif & $10.871,40 \pm 165,29$ \\
Kontrol Normal & $11.012,70 \pm 110,29$ \\
Kontrol Negatif & $11.228 .40 \pm 90.99$ \\
Sambung Nyawa 100\% & $10.549,50 \pm 117,77$ \\
Meniran 100\% & $10.660,50 \pm 245,20$ \\
Dosis 1 & $10.659,60 \pm 171,86$ \\
Dosis 2 & $10.678,50 \pm 130,06$ \\
Dosis 3 & $10.559,40 \pm 116,67$ \\
\hline
\end{tabular}

Kelompok ekstrak daun sambung nyawa $100 \%$ memiliki nilai AUC yang paling kecil dibandingkan dengan kelompok ekstrak lainnya, artinya kelompok ekstrak daun sambung nyawa $100 \%$ memiliki penurunan suhu yang paling baik dibandingkan dengan kelompok ekstrak lain baik tunggal maupun kombinasi (Tabel 2). Sebaran data Area Under Curve (AUC) 
dari suhu tubuh mencit yang diukur selama 300 menit pada 8 kelompok perlakuan dianalisis statistik dengan software IBM SPSS statistic 25. Uji normalitas adalah uji mendasar sebelum melakukan analisis lebih lanjut. Dalam uji normalitas Shapiro-wilk menunjukkan bahwa data pada penelitian terdistribusi normal dengan nilai $\mathrm{p} \geq 0,05$. Kemudian data diuji Levene (homogenitas) dan di dapatkan semua kelompok pada data penelitian memiliki nilai yang homogen dengan nilai $\mathrm{p} \geq 0,05$. Data yang memenuhi kriteria normalitas dan homogenitas kemudian dilakukan analisis parametrik one way ANOVA dan diperoleh nilai signifikansi antar kelompok lebih kecil dari 0,05 ( $\mathrm{p} \leq 0,05)$ yang artinya data berbeda signifikan. Selanjutnya, data dilakukan uji post hoc LSD. Hasil analisis LSD nilai AUC suhu tubuh mencit ditunjukkan pada Tabel 3.

Tabel 3. Hasil Uji Post Hoc AUC suhu tubuh mencit yang diukur selama 300 menit dengan Analisis LSD. Keterangan : tanda $(*)$ menunjukkan terdapat perbedaan signifikan dengan kelompok kontrol. Dosis $1=$ Sambung Nyawa 75\% + Meniran 25\%, Dosis 2 $=$ Sambung Nyawa 50\% + Meniran 50\%, Dosis $3=$ Sambung Nyawa 25\% + Meniran $75 \%$.

\begin{tabular}{|c|c|c|c|c|c|c|c|c|}
\hline Kelompok & $\begin{array}{c}\text { Kontrol } \\
\text { Positif }\end{array}$ & $\begin{array}{l}\text { Kontrol } \\
\text { Normal }\end{array}$ & $\begin{array}{l}\text { Kontrol } \\
\text { Negatif }\end{array}$ & $\begin{array}{c}\text { Sambung } \\
\text { Nyawa } \\
100 \%\end{array}$ & $\begin{array}{c}\text { Meniran } \\
100 \%\end{array}$ & $\begin{array}{c}\text { Dosis } \\
1\end{array}$ & $\begin{array}{c}\text { Dosis } \\
2\end{array}$ & $\begin{array}{c}\text { Dosis } \\
3\end{array}$ \\
\hline Kontrol & & 0,148 & $0,001^{*}$ & $0,002 *$ & $0,034^{*}$ & $0,034^{*}$ & 0,051 & $0,003^{*}$ \\
\hline Positif & & & & & & & & \\
\hline Kontrol & & & $0,031^{*}$ & $0,000 *$ & $0,001 *$ & $0,001^{*}$ & $0,001 *$ & $0,000^{*}$ \\
\hline Normal & & & & & & & & \\
\hline Kontrol & & & & $0,000^{*}$ & $0,000^{*}$ & $0,000 *$ & $0,000 *$ & $0,000^{*}$ \\
\hline Negatif & & & & & & & & \\
\hline Sambung & & & & & & & & \\
\hline Nyawa & & & & & 0,253 & 0,257 & 0,186 & 0,918 \\
\hline $100 \%$ & & & & & & & & \\
\hline Meniran & & & & & & 0,993 & 0,851 & 0,297 \\
\hline $100 \%$ & & & & & & & & \\
\hline Dosis 1 & & & & & & & 0,844 & 0,301 \\
\hline Dosis 2 & & & & & & & & 0,221 \\
\hline Dosis 3 & & & & & & & & \\
\hline
\end{tabular}

Hasil uji lanjutan uji post hoc LSD antara kelompok kontrol positif dan kelompok kontrol negatif memiliki nilai signifikansi $\mathrm{p} \leq 0,05$ yang menunjukkan kelompok kontrol positif dan kelompok kontrol negatif memiliki perbedaan yang signifikan. Nilai AUC kelompok kontrol normal tidak berbeda signifikan $(\mathrm{p} \geq 0,05)$ dengan kelompok kontrol positif tetapi berbeda signifikan $(\mathrm{p} \leq 0,05)$ dengan kelompok kontrol negatif, hal ini menunjukkan bahwa kelompok kontrol positif memiliki penurunan suhu yang mendekati kelompok kontrol normal dan menandakan bahwa metode yang digunakan sudah benar. Nilai AUC semua kelompok perlakuan memiliki perbedaan yang signifikan $(p \leq 0,05)$ dengan kontrol negatif, hal ini menunjukkan bahwa semua kelompok perlakuan memberikan efek penurunan yang lebih baik dibandingkan dengan kelompok kontrol negatif. Nilai AUC antar kelompok perlakuan tidak 
memiliki perbedaan yang signifikan $(\mathrm{p} \geq 0,05)$ hal ini menunjukkan bahwa antar kelompok perlakuan memiliki penurunan suhu yang hampir sama. Dilihat dari hasil AUC, kelompok perlakuan sambung nyawa 100\% memiliki nilai AUC yang paling kecil hal ini menunjukkan bahwa kelompok perlakuan dengan pemberian dosis kombinasi tidak lebih baik dibandingkan dengan dosis tunggalnya.

Hasil penelitian ini didapatkan sebagian suhu setelah diinduksi ragi yang tidak naik, hal ini menandakan ragi yang diinduksikan pada mencit kurang memberikan efek sehingga suhu tidak naik. Suhu setelah diberikan perlakuan juga mengalami naik turun, hal ini disebabkan oleh faktor endogen yaitu imunitas dari dalam tubuh mencit yang berbeda-beda, faktor lingkungan, dan adanya stres dari tubuh mencit karena dilakukan pengukuran rektal yang berulang-ulang (Jansen et al., 2015). Pirogen yang masuk ke dalam tubuh akan bertindak sebagai antigen yang akan memicu sel imun dan menyebabkan terjadinya demam (Potter \& Perry, 2006).

Respon imun terhadap pirogen yang masuk ke dalam tubuh pada setiap individu dapat berbeda-beda, Setiap tubuh individu memiliki termoregulasi dalam mengatur suhu tubuh. Sebagai respons pertahanan tubuh, sel-sel mononuklear mengeluarkan sitokin pro-inflamasi yang mempengaruhi pusat termoregulasi hipotalamus untuk meningkatkan suhu tubuh (Philip, 2013). Menurut penelitian Ibrahim et al. (2014) kombinasi ekstrak yang didapatkan memiliki efek yang lebih baik dibandingkan dengan ekstrak tunggalnya, namun pada penelitian ini tidak didapatkan kombinasi ekstrak yang lebih baik dari ekstrak tunggalnya, sehingga dapat dikatakan bahwa kombinasi kedua ekstrak tidak memberikan efek antipiretik yang sinergis.

\section{Kesimpulan}

Kombinasi ekstrak etanol herba meniran (Phillantus niruri L.) dan daun sambung nyawa (Gynura procumbens L.) memiliki aktivitas antipiretik optimum pada mencit yang diinduksi ragi pada dosis ekstrak daun sambung nyawa $25 \%+$ ekstrak herba meniran $75 \%$. Kombinasi ekstrak etanol herba meniran (Phillantus niruri L.) dan daun sambung nyawa (Gynura procumbens L.) memiliki aktivitas antipiretik tidak lebih baik dari ekstrak tunggal.

\section{Ucapan Terimakasih}

Terimakasih kepada Pusat Pengolahan Pasca Panen Tanaman Obat (P4TO) Dinas Kesehatan Kabupaten Karanganyar untuk simplisia kering meniran terstandar dan Laboratorium Pusat Universitas Sebelas Maret yang telah menyediakan fasilitas penelitian ini.

\section{Deklarasi Konflik Kepentingan}

Semua penulis menyatakan tidak ada konflik kepentingan terhadap naskah ini.

\section{Daftar Pustaka}

Andayani, D., dan Nugrahani, R. (2018). Skrining Fitokimia dan Aktivitas Antioksidan Ekstrak Etanol Daun Katang-Katang (Ipomoea Pescaprae. L) dari Pulau Lombok Nusa Tenggara 
Barat. JPSCR : Journal of Pharmaceutical Science and Clinical Research, 3(2), 76. https://doi.org/10.20961/jpscr.v3i2.21924.

Bagalkotkar, G., Sagineedu, S. R., Saad, M. S., dan Stanslas, J. (2006). Phytochemicals from Phyllanthus niruri Linn. and their pharmacological properties: a review . Journal of Pharmacy and Pharmacology, 58(12), 1559-1570. https://doi.org/10.1211/jpp.58.12.0001.

Budiman, K. dan Effendi, C. (2018), Effect of Glutathione on MDA (Malondyaldehyde) Plasma and Sod (Superoxyde Dysmutase) Erythrocyte on White Rat (Rattus norvegicus) That Exposed Paracetamol, J Pharm Sci Technol, 1(1), pp.13-19.

Chang, C. C., Yang, M. H., Wen, H. M., dan Chern, J. C. (2002). Estimation of total flavonoid content in propolis by two complementary colometric methods. Journal of Food and Drug Analysis, 10(3), 178-182. https://doi.org/10.38212/2224-6614.2748.

Cheng, H. S., Ton, S. H., dan Abdul Kadir, K. (2017). Ellagitannin geraniin: a review of the natural sources, biosynthesis, pharmacokinetics and biological effects. In Phytochemistry Reviews. 16(1). https://doi.org/10.1007/s11101-016-9464-2.

Martino, M., dan Chiarugi, A. (2015). Recent Advances in Pediatric Use of Oral Paracetamol in Fever and Pain Management. Pain and Therapy, 4(2), 149-168. https://doi.org/10.1007/s40122-015-0040-z.

Departemen Kesehatan Republik Indonesia. (1995). Farmakope Indonesia (IV). Jakarta : Departemen Kesehatan Republik Indonesia.

Edwin, T., Ihsan, T., dan Pratiwi, W. (2017). Uji Toksisitas Akut Logam Timbal (Pb), Krom (Cr) Dan Kobalt (Co) Terhadap Daphnia Magna Acute Toxicity Test Of Metal Lead ( $\mathrm{Pb}$ ), Chromium (Cr) And Cobalt (Co) On Daphnia Magna. Jurnal Teknik Lingkungan UNAND, 14(1), 33-40.

Guyton dan Hall. (1997). Buku Ajar Farmakologi Kedokteran (9th ed.). Jakarta : EGC.

Harborne, J. (2006). Metode Fitokimia: Penuntun Cara Modern Menganalisis Tumbuhan. Bandung : Penerbit ITB.

Ibrahim, N., Yusriadi, dan Ihwan. (2014). Uji Efek Antipiretik Kombinasi Ekstrak Etanol Herba Sambiloto (Adrographis paniculata Burm.f. Ness.) dan Ekstrak Etanol Daun Belimbing Wuluh (Averba bilimbi L.) pada Tikus Putih Jantan (Rattus norvegicus). Journal of Natural Science, 3(3), 257-268.

Irwandi, Tobat, S. R., dan Sari, P. P. (2018). Uji Efek Analgetik Ekstrak Etanol Meniran (Phyllanthus niruri L.) Pada Mencit Putih Jantan. Jurnal Akademi Farmasi Prayoga, 3(1), 12-20. http://jurnal.akfarprayoga.ac.id/index.php/JAFP/article/view/26.

Jansen, I., Wuisan, J., dan Awaloei, H. (2015). Uji Efek Antipiretik Ekstrak Meniran (Phyllantus Niruri L.) Pada Tikus Wistar (Rattus Norvegicus) Jantan Yang Diinduksi Vaksin Dpt-Hb. Jurnal E-Biomedik, 3(1), 3-7. https://doi.org/10.35790/ebm.3.1.2015.7427.

Kaewseejan, N., Puangpronpitag, D., dan Nakornriab, M. (2012), Evaluation of Phytochemical Composition and Antibacterial Property of Gynura procumbens Extract, Asian J Plant Sci, 11(2), p.77.

Kaur, N., Kaur, B., dan Sirhindi, G. (2017). Phytochemistry and Pharmacology of Phyllanthus niruri L.: A Review. Phytotherapy Research, 31(7), 980-1004. https://doi.org/10.1002/ptr.5825.

Kementerian Kesehatan RI. (2017). Farmakope Herbal Indonesia Edisi II. Jakarta : Kementerian Kesehatan RI.

Lumowa, S.V. and Bardin, S. (2018), Uji Fitokimia Kulit Pisang Kepok (Musa paradisiacal) Bahan Alam Sebagai Pestisida Nabati Berpotensi Menekan Serangan Serangga Hama Tanaman Umur Pendek, Jurnal Sains dan Kesehatan, 1(9). pp.465-469.

Moreira, J., Klein-Júnior, L. C., Filho, V. C., dan Buzzi, F. D. C. (2013). Anti-hyperalgesic activity of corilagin, a tannin isolated from Phyllanthus niruri L. (Euphorbiaceae). 
Journal of Ethnopharmacology, 146(1), 318-323. https://doi.org/10.1016/j.jep.2012.12.052.

Philip, A. (2013). Mechanism of Fever in Humans. Int J Microbiol Immunol Res, 2, 37-43.

Potter, P.A. dan Perry, A. G. (2006). Buku Ajar Fundamental Keperawatan : Konsep, Proses, dan Praktik (4th ed.). Jakarta : EGC.

Rahmi, S. (2019). Pemanfaatan Ekstrak Daun Sambung Nyawa (Gynura procumbens (Lour.) Sebagai Antipiretik pada Tikus Putih Jantan. In Prosiding Seminar Nasional Hasil Penelitian. 2(2). 1797-1803.

Rivai, H., Nurdin, H., Suyani, H., dan Bakhtiar, A. (2011). Karakterisasi Ekstrak Daun Dewa [Gynura pseudochina (L.) DC] Dengan Kromatografi Cair Kinerja Tinggi. Jurnal Farmasi Indonesia, 5(3), 134-141.

Sasongko, H., Farida, Y., Rohman Efendi, N., Pratiwi, D., Dwi Setyawan, A., dan Widiyani, T. (2016). Analgesic Activity of Ethanolic Extracts of Karika Leaves (Carica pubescens) In Vivo Aktivitas Analgesik Ekstrak Etanol Daun Karika (Carica pubescens) Secara In Vivo. JPSCR: Journal of Pharmaceutical Science and Clinical Research, 01(02), 83-89. https://doi.org/10.20961/jpscr.v1i2.1938.

Sasongko, H., Rahmawati, A. A., Farida, Y., dan Sugiyarto, S. (2019). In-vivo Antipyretic Effect of Eel (Anguilla bicolor bicolor) Oil on Yeast-induced Fever on Mice. ALCHEMY Jurnal Penelitian Kimia, 15(2), 219. https://doi.org/10.20961/alchemy.15.2.27086.219227.

Snyder, L. R., Kirkland, J.J., dan Dolan, J. W. (2009). Introduction to Modern Liquid Chromatography Introduction to Modern Liquid Chromatography Second Edition. Canada : John Wiley \& Sons.

Sweetman, S. C. (2009). Martindale the Complete Drug Reference (36th ed.). London : Pharmaceutical Press.

Tesema, S., dan Makonnen, E. (2015). In Vivo Analgesic and Antipyretic Activities of NButanol and Water Fractions of Ocimum Suave Aqueous Leaves Extract in Mice. Ethiopian Journal of Health Sciences, 25(2), 139-146.

Valério, D. A., Georgetti, S. R., Magro, D. A., Casagrande, R., Cunha, T. M., Vicentini, F. T. M. C., Vieira, S. M., Fonseca, M. J. V., Ferreira, S. H., Cunha, F. Q., dan Verri, W. A. (2009). Quercetin reduces inflammatory pain: Inhibition of oxidative stress and cytokine production. Journal of Natural Products, 72(11), 1975-1979. https://doi.org/10.1021/np900259y.

Winarto W.P, dan K. T. (2003). Sambung Nyawa Budidaya dan Pemanfaatan untuk Obat. Jakarta : Penebar Swadaya.

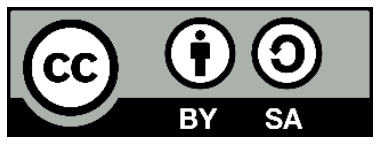

(C) 2021 by the authors. Submitted for possible open access publication under the terms and conditions of the Creative Commons Attribution-ShareAlike 4.0 International (CC BY-SA 4.0) license (https://creativecommons.org/licenses/by-sa/4.0/). 